\title{
System of Exercises for Anglophone Strategic Competence Formation in Future Interpreters
}

\author{
Natalia Sabat \\ Ivan Franko National University of Lviv
}

\begin{abstract}
The article presents the substantiation of the process of development of exercise system aimed at building the Anglophone strategic competence in future interpreters. The system comprises three blocks of exercises according to the three stages of educational program (activation of language material, strategic training and speech simulations) according to the author's methods created specifically to develop the mentioned above competence. The author defines the types of exercises to be used in the exercise system on the basis of generally accepted criteria, but with respect to the specificity of the strategic competence formation in future interpreters. The key position in the system is occupied by the second block comprising four groups of exercises within the scope of the training session.
\end{abstract}

Keywords: future interpreters, strategic competence, strategies, system of exercises.

Навчальний процес, спрямований на формування в майбутніх перекладачів англомовної стратегічної компетентності, проходить у три етапи (активізація мовного матеріалу, стратегічне навчання і мовленнєві симуляції, що передбачають вирішення реальних професійних завдань із застосуванням сформованої стратегічної компетентності).

Фактично на першому етапі (активізація мовного матеріалу) студентська діяльність характеризується як частково самостійна, до певної міри рутинна. Студентам пропонується виконання вправ загального лінгвістичного змісту (оперування відповідним мовним матеріалом англійської мови загального вжитку), а також виконання блоку лексичних завдань на активізацію термінологічної компетентності (у нашому випадку у сфері медицини, економіки чи технологій). На другому етапі (власне стратегічне навчання) відбувається виконання програми комплексу авторських тренінгів. На третьому етапі (застосування) студенти не лише застосовують сформовану стратегічну компетентність (відповідні перекладацькі та комунікативні стратегіï), але й аналізують їх цінність для власної навчально-пізнавальної діяльності, свідомо і самостійно планують алгоритм використання тих чи інших стратегій, самостійно контролюють успішність реалізації цього алгоритму. Усе це відбувається за допомогою мовленнєвих симуляцій. 
Для характеристики розробленої нами підсистеми вправ і завдань зупинимося спершу на розумінні цих ключових понять: вправа і завдання.

Вправою вважають багаторазове виконання однотипних операцій і дій з мовним матеріалом, яка опирається на усвідомленості і супроводжується контролем чи самоконтролем [7, с. 91]; «спеціально організоване в навчальних умовах багаторазове виконання окремих операцій, дій або діяльності 3 метою оволодіння ними або їх вдосконалення» [1, с. 64]. Отже, під завданням розуміємо навчальне завдання, сформульоване в реальному навчальному мовленнєвому контексті, вирішення якого потребує використання відповідних умінь i стратегій (як комунікативних, перекладацьких, так і навчальних); тобто завдання спрямоване на формування і розвиток стратегічної компетентності, а вправа спрямована на формування окремих складових цієї компетентності (мовних навичок, окремих умінь тощо).

У навчальному завданні виділяють певну структуру:

- інструкція (постановка навчальної мети);

- частина виконання, в якій демонструються можливі способи вирішення комунікативного завдання (опори, орієнтири, мовленнєві зразки);

- контрольна частина, яка забезпечує (при потребі) рефлексію, (само)контроль чи (само)корекцію (наприклад, вказівку на теоретичний матеріал, знання якого закладені в алгоритм виконання завдання тощо) [6].

Для вирішення завдань нашого дослідження - розробки методики формування стратегічної компетентності майбутніх перекладачів, необхідно сформувати методичну систему, ключовим елементом якої повинна стати система вправ і завдань, яку розуміємо як систему нижчого порядку (чи підсистему) і складову системи вищого порядку [3], як обгрунтовану й цілеспрямовано впорядковану сукупність необхідних груп, типів і видів вправ i комунікативних завдань, які виконуються студентами у відповідній послідовності, спрямовані на вирішення поставленої дидактичної мети на кожному етапі(відповідно до структури, сутності і специфіки досліджуваного явища (у нашому випадку - англомовної стратегічної компетентності майбутніх перекладачів).

У методиці традиційно визначені основні вимоги до розробки системи вправ $\mathrm{i}$ завдань: 
1) вправи і завдання у системі (підсистемі, комплексі) повинні бути адекватні меті, змісту й умовам навчання загалом;

2) вправи і завдання повинні бути доцільними (до змісту складністю, місцем у системі);

3) завдання і вправи повинні бути організовані у чіткій послідовності у системі: кожна наступна вправа й завданням повинні виконуватися на основі навичок, вмінь i стратегій, сформованих у попередніх вправа і завданнях;

4) зміст вправ, завдань повинен узгоджуватися із етапами формування навичок, умінь і стратегій;

5) вправи і завдання повинні містити можливість для студента здійснення самоконтролю [2, с. 89].

Слідом за Н.К. Скляренко (за цитуванням С. Ю. Ніколаєвої [4] ) та О. Р. Світличною [5, с. 50], ми вважаємо, що основними критеріями типології вправ і завдань у нашій системі повинні бути обрані такі: вмотивованість, ступінь комунікативності, спрямованість навчальної діяльності на прийом або подачу інформації, ступінь керування, спосіб організації та необхідність забезпечення опорами. Враховуючи ці критерії, до розробленої нами підсистеми вправ і завдань увійшли такі типи:

1. Відповідно до критерію вмотивованості: вмотивовані. Майбутній перекладач повинен свідомо розуміти мету виконання вправи і їі розвивальний вплив на формування його професійної перекладацької компетентності.

2. За критерієм спрямованості: рецептивні, рецептивно-репродуктивні та рецептивно-продуктивні вправи і завдання. Рецептивні вправи у нашій підсистемі здебільшого готують майбутнього перекладача до знайдення «зайвого» терміну, пошуку правильної дефініції до терміну. До рецептивно-репродуктивних відносяться вправи на тренування різних видів пам'яті (мнемотехніка, безасоціативне та асоціативне запам'ятовування), розшифрування абревіатур, синонімічний переклад тощо. Продуктивні вправи сприяють розвитку умінь і стратегій прогнозування та розвиток перекладацької здогадки, формування й розвитку стратегії компресії та декомпресії тощо. 
3. Врахування критерію професійної спрямованості зумовило те, що усі вправи i завдання у нашій системі $\epsilon$ професійно спрямованими, тобто мають на меті формування і розвиток професійної компетентності перекладача.

4. Відповідно до критерію наявності/відсутності опор: вправи і завдання 3 використанням вербальних опор, візуальних опор, звукових опор, аудіо-візуальних опор чи без опор.

5. Критерій комунікативності визначив необхідність і доцільність таких вправ у нашій системі (підсистемі): некомунікативні (повтор, імітація, тренування пам'яті), умовно-комунікативні (виконання завдань i вправ для формування окремих перекладацьких стратегій), комунікативні (виконання комунікативних симуляцій).

6. Відповідно до критерію специфіки контролювальних процедур: вправи i завдання, контрольовані з боку викладача, взаємоконтрольовані, з використанням самоконтролю або самоперевірки з використанням технічних засобів.

7. Враховуючи критерій характеру виконання, до системи увійшли усні і письмові вправи (зумовлені обставинами і специфікою типових комунікативних ситуацій у професійній діяльності перекладачів).

8. За критерієм режиму виконання у системі містяться вправи для виконання в парах, у групах та індивідуальні.

Таким чином, підсистема вправ i завдань для формування стратегічної компетентності майбутніх перекладачів складається із трьох блоків вправ і завдань, що узгоджуються із трьома етапами навчального процесу за розробленою нами методикою, спрямованого на формування англомовної стратегічної компетентності майбутніх перекладачів. На рисунку 1 подано схематично структуру авторської підсистеми вправ $\mathrm{i}$ завдань.

\section{References}

1. Bihych, O. B., Haponova, S. V., Hryniuk, H. A. ta in. Metodyka vykladannia inozemnykh mov u serednikh navchalnykh zakladakh: pidruchn. dlia studentiv vyshchykh navch. zakl. / Avtor. kol. pid ker. S. Yu. Nikolaievoi]. Kyiv: Lenvit, 2002.

2. Maksymenko, L. O. Navchannia profesiino spriamovanoho anhlomovnoho dialohu maibutnikh menedzheriv nevyrobnychoi sfery : dys. kand. ped. nauk : 13.00.02. Kyiv: Kyivskyi nats. linhv. un-t, 2012. 
3. Nikolaieva, S. Yu. «Tsili navchannia inozemnykh mov v aspekti kompetentnisnoho pidkhodu.» Inozemni movy, № 2 (2010): 11-17.

4. Nikolaieva, S. Yu. Osnovy suchasnoi metodyky vykladannia inozemnykh mov (skhemy i tablytsi) : Navchalnyi posibnyk. Kyiv: Lenvit, 2008.

5. Svietlichnaya, E. R. «Sistiema uprazhnieniy dlia obuchieniya ustnomu posliedovatielnomu dvustoronniemu profiessionalno orientirovannomu pierievodu.» Sbornik nauchnyih trudov SWorld. Matierialy miezhdunarodnoy nauchnopraktichieskoi konferentsii «Sovriemiennyie probliemy i puti ikh riesheniya v naukie, transporite, proizvodstvie i obrazovanii'2012» (KUPRIENKO) 25, \# 4 (2012): 45-54.

6. Skliarenko, N. K. «Suchasni vymohy do vprav dlia formuvannia inshomovnykh movlennievykh navychok i vmin.» Inozemni movy, № 3 (1999): 3-7.

7. Sysa, E. A. Obuchienie inoyazyichnomu chtieniyu s ispolzovaniem stratiegij na osnovie samostoyatielnoi uchiebno-poznavatielnoi dieyatielnosti (tiehnichieskij vuz, niemietskij yazyk) : dis. ... kand. pied. nauk : 13.00.02. Tomsk: Tomskiy nats. politeh. u-t, 2016. 


\section{Підсистема вправ і завдань для формування стратегічної компетентності майбутніх перекладачів}

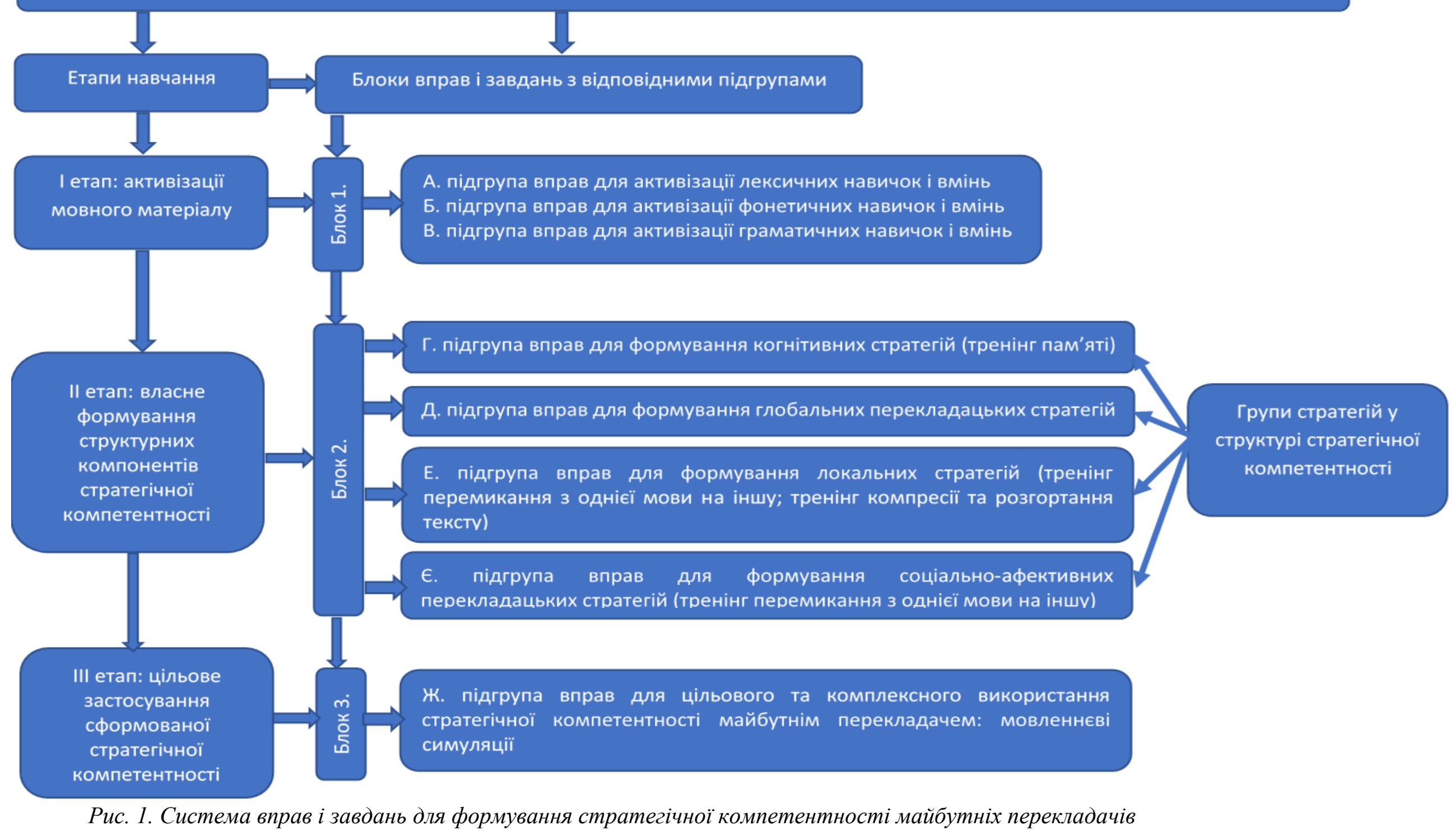

